\section{(Nie)pamięć zbiorowa Polaków jako skuteczna regulacja emocji'}

Michał Bilewicz
Artykułpowstałw ramach grantu NCN Beethoven 2014/15/G/HS6/04589 dotyczącego społecznej percepcji historii.

TEKSTY DRUGIE 2016, NR 6, S. 52-67

DOI: 10.18318/td.2016.6.4

$\mathbf{W}$ badaniach humanistycznych nad pamięcią zbiorową Polaków często pojawiają się odwołania do koncepcji psychologicznych. Zwykle są to jednak inspiracje pochodzące z psychologii klinicznej: z zakresu badań nad traumą bądź psychoanalizy. Przykładem inspiracji badaniami nad zaburzeniami traumatycznymi jest praca Michaela Steinlaufa Pamięć nieprzyswojona. Polska pamięć Zagłady ${ }^{2}$, w której kluczem do zrozumienia polskiej (nie) pamięci Holokaustu były refleksje psychiatry Roberta Jay Liftona dotyczące kontaktu ze śmiercią: poczucia winy wobec śmierci, piętna śmierci oraz niemożności utożsamienia się z ofiarą. Steinlauf przeniósł obserwacje Liftona dotyczące jednostkowych doświadczeń na poziom zbiorowy - i próbował wykorzystać te kategorie do zrozumienia stosunków polsko-żydowskich po Holokauście.

1 Dziękuję Katarzynie Malinowskiej za cenne uwagi do pierwszej wersji tekstu.

2 M.C. Steinlauf Pamięć nieprzyswojona. Polska pamięć zagłady, przeł. A. Tomaszewska, Cyklady, Warszawa 2001.

\section{Michał Bilewicz - \\ psycholog społeczny, profesor Uniwersy- tetu Warszawskiego. Zajmuje się psy- chologią stosunków międzygrupowych oraz psychologicz- nymi podstawami postrzegania historii. Współautor książek The Psychology of Conspiracy (Routled- ge, 2015), Uprzedzenia w Polsce (Liberi Libri, 2015) oraz artykułów na łamach m.in. „Psy- chological Inquiry" $i_{\text {"J Journal of Social }}$ Issues".}


Przykładów inspiracji podejściami wywiedzionymi z psychoanalizy możemy w literaturze dotyczącej polskiej pamięci zbiorowej znaleźć jeszcze więcej (m.in. artykuły Adama Lipszyca czy Agaty Bielik-Robson w niniejszym numerze „Tekstów Drugich”). Jednym z takich przykładów będzie na pewno zastosowana przez Andrzeja Ledera, w Prześnionej rewolucji ${ }^{3}$ koncepcja przyjemności transpasywnej: radości z przemocy dokonywanej przez innego, która pozwala biernej jednostce osiągnąć swoje cele. Koncepcja ta wywodzi się z teorii kultury oraz psychoanalizy lacanowskiej (samo pojęcie „interpasywności" zostało bodaj po raz pierwszy użyte w tym znaczeniu przez Slavoja Žižka ${ }^{4}$ ). Autor Prześnionej rewolucji posługuje się tą koncepcją, by wyjaśnić genezę postaw powojennego społeczeństwa polskiego wobec tych, których nieobecność umożliwiła modernizację.

Wspominam o tych dwóch podejściach, gdyż w obu wypadkach psychologiczne koncepcje wyjaśniające działania i zachowania jednostki zostają przeniesione na poziom społeczeństwa bądź narodu. Tezę o tożsamości procesów indywidualnych i grupowych da się zresztą obronić na gruncie współczesnej wiedzy psychologicznej - tożsamość społeczna (wynikająca z przynależności do grupy, klanu, rodziny, narodu) jest przecież dla psychologów również procesem intrapsychicznym ${ }^{5}$. Przechodząc na poziom myślenia o sobie, jako członku grupy, ludzie dokonują podobnych porównań, odczuwają zbliżone emocje, jak na poziomie indywidualnym. W literaturze psychologicznej czytamy więc coraz częściej o kolektywnym poczuciu winy ${ }^{6}$, o kolektywnym narcyzmie $^{7}$ czy o kolektywnej samoocenie ${ }^{8}-\mathrm{w}$ każdym wypadku są to procesy indywidualne przeniesione na poziom zbiorowy.

3 A. Leder Prześniona rewolucja. Ćwiczenia zlogiki historycznej, Wydawnictwo Krytyki Politycznej, Warszawa 2014.

4 S. Žižek The Interpassive Subject, 1998, http://timothyquigley.net/vcs/interpassive.pdf (22.11.2016).

5 J.C. Turner, H. Tajfel The social identity theory of intergroup behaviour ,',Psychology of intergroup relations" 1986, s. 7-24.

6 J.M. Wohl, N.R. Branscombe, Y. Klar Collective guilt: Emotional reactions when one's group has done wrong or been wronged „„E European Review of Social Psychology” 2006 No. 17/1, s. 1-37.

7 A.G. de Zavala, A. Cichocka, R. Eidelson, N. Jayawickreme Collective narcissism and its social consequences, "Journal of Personality and Social Psychology" 2009 No. 97/6, s. 1074.

8 R. Luhtanen, J. Crocker Self-esteem and intergroup comparisons: Toward a theory of collective self-esteem, w: Social comparison: Contemporary theory and research, ed. by J. Suls, Jerry, T.A. Wills, Lawrence Erlbaum Associates, New Jersey 1991. 
W humanistycznych badaniach nad pamięcią zbiorową inspiracje psychologiczne wydają się od lat ograniczać do psychologii klinicznej oraz psychoterapii. Zaskakująca wydaje się nieobecność tych dziedzin psychologii, które w bardziej naturalny sposób wiążą się z problematyką pamięci - psychologii poznawczej (w której temat pamięci, również zbiorowej', jest bardzo często podejmowany) czy psychologii społecznej - od lat zajmującej się kwestiami winy, odpowiedzialności i pamięci zbiorowej ${ }^{\mathbf{1 0}}$. W niniejszym artykule postaram się przedstawić model (nie)pamięci historycznej oparty na współczesnych odkryciach z zakresu psychologii emocji.

\section{Czym jest skuteczna regulacja emocji?}

W potocznym rozumieniu emocje uważa się za nieracjonalną i impulsywną część natury ludzkiej. W rzeczywistości jednak odczuwanie emocji jest procesem dość złożonej podmiotowej regulacji. W gruncie rzeczy długa tradycja refleksji psychoanalitycznej nad mechanizmami obronnymi w dużej mierze sprowadza się do regulacji emocji lęku. Współcześnie mówimy o regulacji emocji jako działaniu celowym, które polega na skróceniu bądź przedłużeniu oraz zwiększeniu bądź zmniejszeniu siły odczuwania danej emocji. Celem regulacji emocji jest ograniczenie negatywnych emocji (np. smutku, lęku, wstydu, gniewu ${ }^{12}$ ) oraz nasilenie emocji pozytywnych (np. radości, miłości ${ }^{13}$ ). Działanie celowe nie musi być jednak w pełni

9 K. Tuğçe, G. Adams, M. Yellow Bird Generosity or genocide? Identity implications of silence in American Thanksgiving commemorations, "Memory" 2010 No. 18/2, s. 208-224; C.B. Stone, A. Coman, A.D. Brown, J. Koppel, W. Hirst Toward a science of silence the consequences of leaving a memory unsaid, "Perspectives on Psychological Science” 2012 No. 7/1, s. 39-53.

10 J.M. Wohl, N.R. Branscombe, Y. Klar Collective guilt: Emotional reactions when one's group has done wrong or been wronged, s. 1-37; J.W. Pennebaker, D. Paez, B. Rim Collective memory of political events: Social psychological perspectives, Lawrence Erlbaum Associates, New Jersey 1997; O. Klein The lay historian: How ordinary people think about history, w: Narratives and social memory: theoretical and methodological approaches, ed. by R. Cabecinhas, L. Abadia, University of Minho, Braga 2013, s. 25-45.

S. Freud, Neurosis and psychosis, "The Psychoanalytic Review” 1929 nr 16, s. 203.

J.J. Gross, J.M. Richards, O.P. John Emotion regulation in everyday life, „Emotion regulation in couples and families: Pathways to dysfunction and health" 2006, s. 13-35. 
świadome - aktywizacja celu może obejmować zarówno jawne, jak i utajone strategie dążenia bądź unikania ${ }^{14}$.

Proces skutecznej regulacji emocji jest zwykle traktowany w psychologii jako warunek zdrowia psychicznego. W wielu wypadkach - choćby w zaburzeniach lękowych czy zaburzeniach nastroju - problemy z regulacją emocji stanowią kryterium diagnostyczne. Sprawność w stosowaniu poznawczych strategii regulacji emocji ułatwia odraczanie gratyfikacji, radzenie sobie ze stresem i wieloma innymi życiowymi trudnościami ${ }^{15}$. Obecnie najpowszechniej przyjmowanym modelem regulacji emocji jest procesualny model Jamesa Grossa ${ }^{16}$. Model ten podkreśla istnienie dwóch kategorii mechanizmów regulacyjnych: są to mechanizmy regulacji wyprzedzającej pojawienie się emocji (antecedent-focus) oraz mechanizmy korygujące pojawiającą się emocję (response-focus).W modelu tym poszczególne strategie następują po sobie: na początku jest to selekcja sytuacji (np. unikanie sytuacji, w których mógłby się pojawić bodziec wywołujący negatywną emocję), modyfikacja sytuacji (w sposób pozwalający uniknąć tego bodźca), ukierunkowanie uwagi (odwrócenie jej od bodźca wywołującego emocje i skupienie jej na czymś innym), poznawcza reinterpretacja (reinterpretacja bodźca w sposób niewywołujący emocji), a w końcu próba modulacji reakcji emocjonalnej (np. tłumienie emocji). Wcześniejsze mechanizmy regulacji - zwane strategiami wyprzedzającymi - uznawane są za bardziej skuteczne, natomiast ostatnie z nich (szczególnie modulacja reakcji emocjonalnej) są znacznie mniej skuteczne.

Choć procesualny model regulacji emocji jest dziś szeroko stosowany w psychologii zdrowia, a nawet ma uzasadnienie na gruncie neuronauki ${ }^{17}$, warto zastanowić się nad jego znaczeniem w badaniach dotyczących pamięci zbiorowej, a szczególnie w kontekście emocji moralnych związanych z postrzeganiem przeszłości, takich jak wstyd, żal czy wina.

14 A.W. Kruglanski Goal systems theory: Integrating the cognitive and motivational aspects of self-regulation, "Motivated social perception: The Ontario symposium” 2003 No. 9.

15 J.J. Gross, O.P. John Individual differences in two emotion regulation processes: implications for affect, relationships, and well-being, "J) Journal of Personality and Social Psychology" 2003 No. 85/2, s. 348 .

J.J. Gross The emerging field of emotion regulation: an integrative review, "Review of General Psychology" 1998 No. 2/3, s. 271; J.J. Gross Emotion regulation: taking stock and moving forward, s. 359 .

17 A. Etkin, C. Büchel, J.J. Gross The neural bases of emotion regulation, "Nature Reviews Neuroscience" 2015 No. 16/11, s. 693-700. 


\section{Zagrażająca wiedza historyczna}

„Odczuwamy do dziś ból i wstyd z powodu tego, co się wtedy stało"18, oświadczył prezydent Bronisław Komorowski w 70. rocznicę mordu w Jedwabnem, w miejscu, w którym dekadę wcześniej prezydent Aleksander Kwaśniewski ogłosił: „Przepraszam w imieniu swoim i tych Polaków, których sumienie jest poruszone tamtą zbrodnią, w imieniu tych, którzy uważają, że nie można być dumnym z wielkości polskiej historii, nie odczuwając jednocześnie bólu i wstydu z powodu zła, które Polacy wyrządzili innym" ${ }^{\prime 19}$. Konfrontacja z historią zbrodni dokonanej przez członków własnego narodu może wywoływać wiele awersyjnych emocji - również tych, które wymienili w swoich przemówieniach obaj Prezydenci RP. Czy jednak ich emocje były zgodne z odczuciami innych Polaków?

Informacje o historycznych zbrodniach zagrażają pozytywnej tożsamości społecznej. Przynależność do jakiejkolwiek grupy społecznej czy instytucji pełni ważną psychologiczną funkcję - pozwala podnieść samoocenę tym osobom, które utożsamiają się z daną grupą ${ }^{20}$. Zwycięstwa grupy własnej (choćby sukcesy sportowe), podobnie jak wizerunek grupy jako moralnej (choćby przez pomoc innym) pozwalają odczuwać emocje podobne jak w wypadku własnych sukcesów - dumę i satysfakcję. Wydarzenia świadczące o niemoralności grupy powodują awersyjne emocje, których ludzie zwykle unikają. Badania Oliviera Kleina, Laurenta Licaty i Sabriny Pierucci wykazały, że konfrontacja z historią zbrodni dokonanych przez własny naród wywołuje odczucia winy tylko wśród bardzo specyficznej kategorii członków grupy osób o umiarkowanych poziomach identyfikacji z grupą ${ }^{21}$. Badacze przedstawili grupie Belgów historię zbrodni dokonywanych w Kongo przez belgijskich kolonizatorów w epoce króla Leopolda II (na przełomie XIX i XX wieku). Później mierzyli deklarowane przez badanych emocje. Zauważyli, że emocja winy pojawiła się wyłącznie u tych badanych, którzy średnio identyfikowali się z Belgią. U osób o słabej identyfikacji, a zatem takich, dla których dużo

18 B. Komorowski List prezydenta odczytany w Jedwabnem, 10.07.2011, http://www.prezydent.pl/ archiwum-bronislawa-komorowskiego/aktualnosci/wypowiedzi-prezydenta/inne/art,47,list-prezydenta-odczytany-w-jedwabnem.html (22.11.2016).

19 A. Kwaśniewski Przemówienie prezydenta na uroczystościach żałobnych w/edwabnem, 10.07.2001, http://www.prezydent.pl/aleksandra-kwasniewskiego/aktualnosci/rok-2001/art,157,470, prezydent-rp-wzial-udzial-w-uroczystosciach-zalobnych-w-jedwabnem.html (22.11.2016).

J.C. Turner, H. Tajfel The social identity theory of intergroup behaviour, s. 7-24.

21 O. Klein, L. Licata, S. Pierucci Does group identification facilitate or prevent collective guilt about past misdeeds? Resolving the paradox „"British Journal of Social Psychology” 2011 No. 50/3, s. 563-572. 
ważniejsze od bycia Belgiem było bycie Walończykiem, mężczyzną, studentem czy mieszkańcem Brukseli, informacja o zbrodniach dokonanych w Kongo nie wywołała silnych emocji. Podobnie u osób o bardzo silnej identyfikacji. Osoby o bardzo słabej identyfikacji mogą łatwo odrzucić odpowiedzialność („to nie ma ze mną nic wspólnego - to jacyś Belgowie”), zaś osoby o silnej identyfikacji nie przyjmują żadnych krytycznych informacji o własnej grupie („my Belgowie nigdy byśmy się tak nie zachowali”). Wszystko to powoduje, że emocje moralne związane $\mathrm{z}$ historią własnych zbrodni są niezmiernie rzadkie.

W 2013 roku Colin Leach i współpracownicy ${ }^{22}$ podsumowali bardzo liczne badania psychologów społecznych nad emocjami wstydu i winy, odczuwanymi przez narody niegdyś odpowiedzialne za masowe zbrodnie. Przestudiowali dane z badań Holendrów, Belgów, Brytyjczyków i Portugalczyków w kontekście zbrodni kolonialnych; Australijczyków, Chilijczyków i Amerykanów w kontekście zbrodni wobec ludności indiańskiej i aborygeńskiej; Niemców, bośniackich Serbów i rwandyjskich Hutu w kontekście ludobójstwa oraz Norwegów w kontekście przymusowej sterylizacji w latach 30. Podczas zdecydowanej większości tych badań kolektywne emocje winy czy wstydu praktycznie się nie pojawiały. Badani zapytani, czy odczuwają te emocje, odpowiadali zwykle „nie” bądź „zdecydowanie nie”, odmawiając jakiejkolwiek zbiorowej odpowiedzialności za historyczne zbrodnie czy nadużycia. Emocje takie jak zbiorowe poczucie winy czy wstydu - choć pojawiają się często w debacie publicznej, w ustach polityków i wypowiedziach intelektualistów - są w społeczeństwach uwikłanych w historyczne zbrodnie reakcją niezmiernie rzadką.

\section{Unikanie winy jako proces regulacji emocji}

Skoro emocje winy i wstydu są tak rzadką reakcją na historię o zbrodniach dokonanych przez własny naród, można przypuszczać, że istnieją mechanizmy psychologiczne umożliwiające skuteczną regulację tych emocji. Jednym z dowodów na istnienie takich mechanizmów są niedawne eksperymenty Keren Sharvit ${ }^{23}$ z Uniwersytetu w Hajfie, która wraz z współpracownikami wykazała, że emocja winy pojawia się nawet u osób bardzo silnie

C.W. Leach, F.B. Zeineddine, S. Cehajic-Clancy Moral immemorial: The rarity of self-criticism for previous generations' genocide or mass violence, "Journal of Social Issues" 2013 No. 69, s. 34-53.

23 K. Sharvit, M. Brambilla, M. Babush, F.P. Colucci To feel or not to feel when my group harms others? The regulation of collective guilt as motivated reasoning, "Personality and Social Psychology Bulletin" 2015 No. 41, s. 1223-1235. 
identyfikujących się z własnym narodem - ale tylko w warunkach obciążenia zasobów poznawczych. W kilku badaniach eksperymentalnych ich uczestnicy musieli zapamiętywać ciagi liczb w czasie czytania o naruszeniach zasad moralnych przez swoich rodaków (w grupach kontrolnych badani po prostu czytali o takich naruszeniach, bez jednoczesnego zadania zapamiętania ciagu liczb). Osoby badane, dla których przynależność narodowa była niezwykle ważna, w bardzo małym stopniu odczuwały winę, słysząc o niemoralnym zachowaniu swoich rodaków. Gdy jednak obciążono ich zasoby poznawcze równoległym zadaniem zapamiętywania liczby, badani silnie identyfikujący się z narodem zaczynali odczuwać winę czasem nawet silniej niż osoby o słabej identyfikacji. Eksperymenty te przekonują, że proces regulowania emocji winy wymaga zasobów poznawczych - a ich mniejsza dostępność uniemożliwia skuteczną regulację niechcianej emocji.

Próbując zrozumieć, jakie strategie wykorzystywane są do regulacji negatywnych emocji w procesie reagowania na informacje o zbrodniach dokonywanych przez grupę własną, pozwoliłem sobie zastosować ramy pojęciowe procesualnego modelu regulacji emocji Jamesa Grossa ${ }^{24}$, który pozwala wyjaśnić wiele wyników badań prowadzonych w moim zespole, a także w innych ośrodkach badających reakcje na zagrażającą historię. Schemat tego modelu przedstawia ryc. 1

\begin{tabular}{|c|c|c|c|c|}
\hline $\begin{array}{l}\text { Selekcja } \\
\text { sytuacji }\end{array}$ & $\begin{array}{c}\text { Modyfikacja } \\
\text { sytuacji }\end{array}$ & $\begin{array}{l}\text { Ukierunko- } \\
\text { wanie uwagi }\end{array}$ & $\begin{array}{c}\text { Przekształ- } \\
\text { cenia po- }\end{array}$ & $\begin{array}{c}\text { Modulacja } \\
\text { ekspresji }\end{array}$ \\
\hline $\begin{array}{l}\text { - Unikanie } \\
\text { kontaktu } \\
\text { ze źródłem } \\
\text { informacji } \\
\text { - Koncen- } \\
\text { tracja na } \\
\text { przyszłości } \\
\text { zamiast } \\
\text { przeszłości }\end{array}$ & $\begin{array}{l}\text { - Kwestio- } \\
\text { nowanie } \\
\text { źródła } \\
\text { - Cenzura } \\
\text { historycz- } \\
\text { na i prze- } \\
\text { milczanie }\end{array}$ & $\begin{array}{l}\text { - Rywa- } \\
\text { lizacja } \\
\text { cierpień } \\
\text { - Zaprze- } \\
\text { czanie } \\
\text { przeszłości } \\
\text { - Teorie } \\
\text { spiskowe }\end{array}$ & $\begin{array}{l}\text { - Etnocen- } \\
\text { tryzm } \\
\text { w wyjaś- } \\
\text { nieniach } \\
\text { - Odczło- } \\
\text { wieczenie } \\
\text { ofiar } \\
\text { - Umniej- } \\
\text { szanie } \\
\text { konse- } \\
\text { kwencji } \\
\text { działania }\end{array}$ & $\begin{array}{l}\text { - Tłumienie } \\
\text { reakcji } \\
\text { emocjo- } \\
\text { nalnej } \\
\text { - Wybór } \\
\text { „bez- } \\
\text { piecznej” } \\
\text { emocji }\end{array}$ \\
\hline
\end{tabular}

Ryc. 1. Model regulacji emocji w reakcji na zagrażającą informację historyczną

24 M. Bilewicz The dark side of emotion regulation: Historical defensiveness as an obstacle in reconciliation, „Psychological Inquiry” 2016 No. 27/2 s. 89-95. 
Poszczególne strategie regulacyjne przedstawione w modelu stanowią tylko przykłady reakcji, które były dotąd poddawane badaniom psychologów społecznych. By zrozumieć wykorzystanie tych strategii, można odwołać się do polskiej debaty na temat zbrodni w 1941 roku w Jedwabnem oraz współczesnych odprysków tej debaty. Impulsem do jej rozpoczęcia była książka Sasiedzi. Historia zagłady żydowskiego miasteczka Jana Tomasza Grossa oparta na znanej wcześniej polskim historykom - lecz nieznanej szerszej opinii publicznej - relacji ocalałego mieszkańca Jedwabnego, Szmula Wasersztajna.

W reakcji na nową wiedzę o zbrodni dokonanej przez polskich mieszkańców Jedwabnego część odbiorców zadeklarowała chęć skoncentrowania się na innych epizodach historii zamiast konfrontacji z historią Jedwabnego. W jednym z ważnych artykułów z tamtego czasu na łamach „Rzeczpospolitej" historyk Andrzej Nowak proponował skoncentrowanie się na chwalebnych kartach historii narodu, tytułując artykuł Westerplatte czy Jedwabne $e^{25}$. Inną strategią selekcyjną jest unikanie informatora. Można to było zauważyć w sejmowym przesłuchaniu kandydatów na prezesa IPN, w którym późniejszy prezes tej Instytucji dr Jarosław Szarek oświadczył, że Jan Tomasz Gross nie powinien pojawiać się na konferencjach naukowych dotyczących historii Polski ${ }^{26}$. Strategia selekcji sytuacji jest stosunkowo najskuteczniejszą metodą uniknięcia pojawienia się emocji wstydu bądź winy.

W konfrontacji z historią Jedwabnego znajdziemy też wiele przykładów modyfikacji sytuacji - a zatem takiego jej ujęcia, w którym wiedza przestanie być zagrażająca. Próbą modyfikacji sytuacji były wszelkie zabiegi dyskredytujące kompetencje zawodowe autora Sąsiadów..., podkreślające brak jego formalnego wykształcenia historycznego. „Gross - nie historyk, lecz performer”, zatytułował swój komentarz jeden z publicystów „Rzeczpospolitej”27. Warto tu wspomnieć list Amerykańskiego Towarzystwa Historycznego (AHA), organizacji zrzeszającej 12000 amerykańskich historyków, którzy wystąpili do polskiego rządu w obronie Jana Tomasza Grossa, podkreślając jego kompetencje

25 A. Nowak Westerplatte czy Jedwabne, 1.08.2001, http://archiwum.rp.pl/artykul/347318-Westerplatte-czy-Jedwabne.html (22.11.2016).

Kandydat na szefa IPN o Jedwabnem: Wykonawcami zbrodni byli Niemcy, którzy wykorzystali Polaków, 19.07.2016, http://wiadomosci.dziennik.pl/polityka/artykuly/52680o,kandydat-naszefa-ipn-o-jedwabnem-wykonawcami-zbrodni-byli-niemcy-ktorzy-wykorzystali-polakow. html (22.11.2016). 
historyczne - zareagowali na inną strategię regulacyjną, jaką są próby cenzurowania (przez działania polskiej prokuratury wobec historyka) ${ }^{28}$. Modyfikacja sytuacji - obejmująca próby cenzurowania źródła informacji i jego dyskredytacji - również pozwala odsunąć odczuwanie awersyjnych emocji.

Ukierunkowaniem uwagi w debacie o Jedwabnem było podkreślenie marginalnego charakteru sprawców zbrodni, a zatem wyłączenie ich ze wspólnoty narodowej (co psychologia społeczna nazywa efektem „czarnej owcy"29). Przykładem tego mogą być wypowiedzi historyka Tomasza Strzembosza, który analizując ten mord, pisał, że mamy tam „do czynienia nie ze «społeczeństwem Jedwabnego», lecz grupą kilkudziesięciu mężczyzn, spośród których może największego winowajcę - Karola Bardonia, dość trudno uznać za reprezentanta polskości (urodzony na Śląsku Cieszyńskim, żołnierz niemiecki w czasie I wojny światowej, zaufany, bo już na początku okupacji służący w żandarmerii), a dwaj inni to znany w mieście ze skłonności do awantur, pijak oraz znany bandyta" ${ }^{\prime 30}$. Ta strategia pozwala nadal odczuwać pozytywne emocje, gdy myśli się o historii własnego narodu, a sprawców dowolnej zbrodni wyeliminować ze wspólnoty narodowej. Inną strategią ukierunkowania uwagi jest koncentracja na motywacjach historyków - w czasie debaty o Jedwabnem niezwykłą popularność zyskały tezy amerykańskiego politologa dr. Normana Finkelsteina, który na łamach polskiej prasy przekonywał czytelników, że oto autor Sąsiadów... jest elementem spisku historyków i instytucji wymuszających odszkodowania powojenne ${ }^{31}$. Teorie spiskowe pozwalają odsunąć treść ujawnianej wiedzy, a zatem ograniczają też odczuwanie nieprzyjemnych emocji moralnych.

Najciekawsze dla psychologów społecznych są oczywiście te strategie regulacji emocjonalnej, które należą do kategorii poznawczych reinterpretacji.

28 P. Manning Letter of Concern to Polish Government regarding Treatment of Historian Jan Gross, 14.11.2016, https://www.historians.org/news-and-advocacy/statements-and-resolutions-ofsupport-and-protest/letter-of-concern-to-polish-government-regarding-treatment-ofhistorian-jan-gross

(22.11.2016).

29 J.M. Marques, V.Y. Yzerbyt, J.P. Leyens The "black sheep effect": Extremity of judgments towards ingroup members as a function of group identification, "European Journal of Social Psychology" 1988 No. 18/1, s. 1-16.

T. Strzembosz Inny obraz sqsiadów, 31.03.2001, http://archiwum.rp.pl/artykul/330587-Inny-obraz-sasiadow.html (22.11.2016).

31 N.G. Finkelstein Goldhagen dla poczq̨tkujących, 20.06.2001, http://www.geocities.ws/jedwabne/goldhagen_dla_poczatkujacych.htm (22.11.2016). 
Tutaj mieszczą się wszelkie procesy atrybucji przyczynowych - a zatem spontanicznych wyjaśnień, które pozwalają przyjąć same fakty przy jednoczesnym umniejszeniu ich znaczenia dla historii grupy. W wypadku debaty o Jedwabnem oznaczało to podkreślanie zewnętrznych przyczyn zbrodni (atrybucja sytuacyjna), a zatem: wpływu niemieckich okupantów, tak jak to widzimy w wizerunku mordu jedwabieńskiego naszkicowanym przez prof. Tomasza Strzembosza na łamach „Rzeczpospolitej”: „Decydująca - jako inspiratorzy, organizatorzy i współsprawcy - rola Niemców i udział kilkudziesięciu Polaków, w tym także przymuszonych" ${ }^{\text {"32 }}$. Etnocentryzm atrybucyjny obejmuje też niedocenianie wszelkich przyczyn wewnętrznych (osobowościowych, ideologicznych) - zatem ignorowanie wszystkich przesłanek sugerujących, że mieszkańcy Jedwabnego dokonali mordu kierując się chęcią rabunku, antysemickimi uprzedzeniami czy też rozpowszechnioną na tym terenie ideologią narodową ${ }^{33}$. Strategie poznawczej reinterpretacji wydarzenia pozwalają zachować pozytywny wizerunek grupy mimo powierzchownego uznania dla faktów. Te specyficzne wyjaśnienia przyczynowe z czasem pozwalają jednak odrzucić też same fakty - o czym można było się przekonać w czasie przesłuchania sejmowego, gdy ówczesny kandydat na prezesa IPN, dr Jarosław Szarek, oświadczył że „wykonawcą tej zbrodni byli Niemcy, którzy wykorzystali w tej machinie własnego terroru, pod przymusem, grupkę Polaków. Tutaj odpowiedzialność w pełni za tę zbrodnię pada na niemiecki totalitaryzm". W ten sposób na bazie etnocentrycznych atrybucji, przenoszących odpowiedzialność na Niemców jako inspiratorów zbrodni, można wręcz zakwestionować fakt sprawstwa Polaków w zbrodni przez specyficzne użycie sformułowania ,wykonawca".

W sytuacji, gdy wszystkie poprzednie strategie regulacji emocji okazują się nieskuteczne, możliwe jest modulowanie ekspresji emocjonalnej - choćby przez tłumienie pojawiających się awersyjnych emocji. W debacie o Jedwabnem i zachowaniach Polaków w czasie okupacji hitlerowskiej znamienne wydaje się określenie „pedagogika wstydu”. W 2012 roku jeden z polskich polityków ogłosił: „Koniec z pedagogiką wstydu, koniec z tą nieustanną ekspiacją naszego narodu nie wiadomo za co, samooskarżaniem się, bo gromy i mordy ludności żydowskiej w Łomżyńskiem i na Białostocczyźnie latem 1941 roku w świeK. Persak, t. 1, Instytut Pamięci Narodowej, Warszawa 2002. 
to właśnie ułatwia i wręcz zachęca do tego rodzaju działań, to powoduje dla nas straszliwe straty"34. Próba powstrzymania społecznych ekspresji emocji wstydu to typowy korygujący mechanizm reakcji emocjonalnej, który nie jest skuteczny, jako że tłumienie nie pozwala usunąć samego faktu z pola uwagi. Negatywny fakt nadal pozostaje - stąd tak duże zaangażowanie w budowę wcześniejszych, skuteczniejszych strategii wyprzedzających, czyli selekcji sytuacji, modyfikacji, ukierunkowania uwagi i poznawczej reinterpretacji.

Powyższe przykłady dotyczące polskiej debaty o Jedwabnem pokazują, jak wobec jednego wydarzenia historycznego o dużym potencjale wywoływania emocji moralnych można zastosować bardzo szerokie spektrum strategii regulujących negatywne emocje.

\section{Psychologiczne badania regulacji emocji historycznych}

Wiele badań psychologicznych zdaje się potwierdzać systematyczne wykorzystywanie strategii regulowania emocji historycznych. Warto zacząc od selekcji informacji. Istnieją silne dowody, że emocje moralne są powiązane z unikaniem grupy obcej. Gdy ludzie są konfrontowani z informacją wywołującą emocje winy, wówczas zaczynają unikać obcych w swoim otoczeniu - nie chcą mieć bowiem do czynienia z grupą uświadamiającą im przeszłe niegodne zachowania. Potwierdziły to badania, które prowadziliśmy zarówno w Polsce, jak i w Niemczech ${ }^{35}$. Konfrontacja z negatywną historią motywuje ludzi do koncentracji uwagi na tych epizodach historii, w których rodacy zachowali się godnie - np. ratując Żydów w czasie okupacji hitlerowskiej - i przeszacowania skali takich zachowańn ${ }^{36}$. Ludzie o silnej, narcystycznej identyfikacji z grupą będą też domagać się cenzurowania historii - dzięki czemu modyfikują sytuację, uciszając źródło niechcianej informacji ${ }^{37}$.

34 J. Kaczyński Reakcja na wypowiedź amerykańskiego prezydenta Baracka Obamy o „polskim obozie śmierci", 30.05.2012, http://wiadomosci.wp.pl/kat,1342,title,Kaczynski-narod-Polski-zostalobrazony-w-sposob-niezwykle-drastyczny,wid,14529880,wiadomosc.html (22.11.2016).

35 R. Imhoff, M. Bilewicz, H. Erb Collective regret versus collective guilt: Different emotional reactions to historical atrocities ,",European Journal of Social Psychology" 2012 No. 42/6, s. 729-742.

36 M. Bilewicz, A. Stefaniak, M. Witkowska Polish youth confronting the Jewish past. Antagonistic history and pathways to reconciliation, w: Reconciliation in Bloodlands. Assessing actions and outcomes in contemporary Central-Eastern Europe, ed. by J. Kurczewski, Peter Lang, London 2014, s. 97-112.

37 Y. Klar, M. Bilewicz From socially motivated lay historians to lay censors: Case studies from Israel and Poland, w druku. 
Badania psychologiczne wskazują też na rozliczne strategie ukierunkowania uwagi. Jednym $\mathrm{z}$ dobrze znanych mechanizmów jest tu rywalizacja cierpień: podkreślanie własnych cierpień w celu wyciszenia myśli o zbrodniach dokonanych przez rodaków. Koncentracja na własnych cierpieniach pozwala uzasadnić swoje brutalne zachowania wobec obcych oraz przemilczeć ich cierpienia ${ }^{38}$. Jednocześnie pozwala nie dostrzegać cierpień tych narodów, które zostały skrzywdzone przez inne narody - a które mogłyby stać się rywalami w walce o status największej ofiary historiii" ${ }^{39}$. Wszystko to pozwala uznać rywalizację cierpień za sposób unikania emocji wstydu czy winy wobec innych narodów. Koncentracja na byciu ofiarą skłania w końcu do interpretacji świata w kategoriach spisku - skoro w historii świat sprzysiagł się przeciw nam, to dzisiejsze wydarzenia należy również interpretować w ten sposób. Wtedy to ujawnienie mrocznych kart historii narodu będzie traktowane jako kolejne narzędzie w ręku wrogów naszego narodu, dążących do jego unicestwienia. Liczne badania, które prowadziliśmy w Polsce i w Grecji, pokazują, że koncentracja na historycznych cierpieniach ułatwia myślenie o świecie i polityce w kategoriach spiskowych ${ }^{40}$.

Spośród strategii poznawczej reinterpretacji warto skoncentrować się na trzech, które wydają się najpowszechniej stosowane: dehumanizacji ofiar, moralnym przełączaniu się oraz etnocentrycznych atrybucjach. Mirosław Kofta i Patrycja Sławuta konfrontowali uczestników badania z opisem pogromów dokonywanych przez Polaków na Żydach bezpośrednio po zakończeniu II wojny światowej ${ }^{41}$. Zauważyli, że po przeczytaniu takiej informacji

38 M. Bilewicz, A. Stefaniak Can a victim be responsible? Anti-Semitic consequences of victimhood-based identity and competitive victimhood in Poland, w: Responsibility: An interdisciplinary perspective, ed. by B. Bokus, Lexem, Warszawa 2013, s. 69-77; M. Noor, N. Shnabel, S. Halabi, A. Nadler When suffering begets suffering the psychology of competitive victimhood between adversarial groups in violent conflicts, "Personality and Social Psychology Review” 2012 No. 16/4, s. 351-374; M. Bilewicz, M.M. Winiewski, M. Kofta, A. Wójcik Harmful Ideas. The structure and consequences of antisemitic beliefs in Poland , Political Psychology” 2013 No. 34/6, s. 821-839;

M. Bilewicz, A. Stefaniak Can a victim be responsible? Anti-Semitic consequences of victimhood-based identity and competitive victimhood in Poland; J.R. Vollhardt, M. Bilewicz, M. Olechowski Victims under siege: Lessons for Polish-Jewish relations and beyond, w: The social psychology of intractable conflicts, ed. by E. Halperin, K. Sharvit, Springer International Publishing, Nowy Jork, 2015.

M. Witkowska, M. Bilewicz, M. Pantazi, T. Gkinopoulos, O. Klein 'Historia est Magistra'? The Impact of Historical Victimhood on Current Conspiracy Beliefs, w recenzji. moral disapproval of Polish atrocities against Jews after the Holocaust, "Journal of Social Issues" 2013 No. 69/1, s. 54-73. 
badani przestawali dostrzegać emocje u ofiar - ale tylko wtedy, kiedy to grupa własna (Polacy) była sprawcą mordów. Tego rodzaju dehumanizacja, polegająca na niedostrzeganiu wyższych uczuć u ofiar może w końcu osłabiać współczucie - jak pokazują choćby badania prowadzone w Bośni czy Chi$\mathrm{le}^{\mathbf{4 2}}$. Dehumanizacja jest więc skuteczną strategią regulacji emocji moralnych: myśląc o ofiarach jak o nieodczuwających emocji zwierzętach, można powstrzymać swoje własne emocje. Inną strategią, która temu służy, jest moralne przełączanie się, opisane w amerykańskich badaniach Benhardta Leidnera i Emanuele Castano ${ }^{43}$. Zwrócili oni uwagę na to, że badani skonfrontowani z informacją o niemoralnym zachowaniu rodaków zmieniają sposób myślenia o moralności - wyłączają etykę troski i sprawiedliwości, a włączają etykę lojalności i posłuszeństwa. Ich myślenie o tym, co stanowi istotę moralności, staje się zupełnie inne - to człowiek posłuszny grupie jest w ich oczach uczciwy, a nie człowiek troszczący się o dobro innych. Ta zmiana kategorii moralnych umożliwia podtrzymanie dobrego samopoczucia w sytuacji zagrożenia tożsamości przez informację o niemoralnym zachowaniu rodaków.

Najlepiej zbadaną strategią poznawczej reinterpretacji są etnocentryczne atrybucje. Badania przeprowadzone na reprezentatywnej ogólnopolskiej próbie w trakcie debaty o Jedwabnem wykazały, że Polacy w rok po ukazaniu się książki na temat tej zbrodni zdecydowanie chętniej wybierali atrybucje sytuacyjne (m.in. szukające przyczyn w zachowaniach Żydów lub Niemców) niż atrybucje dyspozycyjne (m.in. wyjaśniające zbrodnie antysemityzmem sprawców) ${ }^{\mathbf{4 4}}$. W kolejnych badaniach przyglądaliśmy się strukturom wyjaśnień konfliktów, w których obie strony dokonywały zbrodni. W badaniach dotyczących zbrodni w Pawłokomie (gdzie na terenie okolicznych wiosek dochodziło do mordów dokonanych przez polskie podziemie na Ukraińcach i zbrodni dokonanych przez UPA na Polakach) zauważyliśmy, że przedstawienie opisu zbrodni młodym Polakom doprowadza do pojawienia się atrybucji etnocentrycznych - Polacy zbrodnicze działania swoich rodaków tłumaczą bardziej sytuacyjnie, natomiast zbrodnicze działania przeciwników chętniej

42 S. Čehajić, R. Brown, R. González What do I care? Perceived ingroup responsibility and dehumanization as predictors of empathy felt for the victim group , Group Processes \& Intergroup Relations" 2009 No. 12/6, s. 715-729.

43 B. Leidner, E. Castano Morality shifting in the context of intergroup violence „European Journal of Social Psychology" 2012 No. 42/1, s. 82-91.

44 M. Bilewicz Wyjaśnianie Jedwabnego, w: Antysemityzm w Polsce i na Ukrainie. Raport z badań, red. I. Krzemiński, Scholar, Warszawa 2004. 
tłumaczą dyspozycyjnie ${ }^{45}$. Jest to o tyle ciekawe, że etnocentryzm atrybucyjny pojawiał się u osób bardzo młodych, które o zbrodniach w Pawłokomie wcześniej nic nie wiedziały.

W najbardziej systematycznych badaniach tego zjawiska próbowaliśmy zrozumieć, czy etnocentryzm atrybucyjny wynika z silnej identyfikacji czy raczej z potrzeby domknięcia poznawczego (chęć posiadania pewnej, konkretnej wiedzy).W serii dwóch badań przedstawiliśmy badanym Polakom historie pozytywnych bądź negatywnych zachowań ich rodaków (w pierwszym badaniu dotyczyło to zachowań Polaków i Niemców wobec Żydów na terenie Generalnego Gubernatorstwa; w drugim - zachowań Polaków i Niemców w czasie interwencji w Czechosłowacji w 1968 roku). Badanie to potwierdziło, że czytając o niemoralnym zachowaniu rodaków, ludzie rzadziej wybierają wyjaśnienia dyspozycyjne niż wtedy, gdy czytają o niemoralnym zachowaniu obcego narodu albo o moralnym zachowaniu własnego narodu. Etnocentryzm atrybucyjny widoczny jest głównie u osób o bardzo silnej identyfikacji narodowej. W wypadku wiedzy wcześniej znanej osobom badanym (wydarzenia w czasie okupacji hitlerowskiej) etnocentryzm atrybucyjny był też wynikiem zdolności domykania poznawczego, a zatem umiejętności odrzucania wiedzy niepasującej do zastanych struktur myślenia. Jest to kolejny dowód na to, że strategie regulacji emocji (w tym wypadku etnocentryczne atrybucje) są tak naprawdę zdolnością do przetwarzania wiedzy - która w tym wypadku pozwala oddalić nieprzyjemne emocje.

\section{Czy można wyjść poza zaklęty krąg sprawnej regulacji emocji?}

Skoro polska (nie)pamięć zbiorowa jest wynikiem sprawnie funkcjonujących procesów przetwarzania emocji, to czy istnieje jakikolwiek sposób na przyswojenie sobie przez Polaków wiedzy o negatywnych wydarzeniach z historii ich narodu? Wydaje się, że sposobem na to mogłoby być odejście od języka emocji w dyskusjach o historii. Jak już wcześniej zauważono, nawet w wypowiedziach obu Prezydentów RP dotyczących Jedwabnego pojawiało się odwołanie do emocji winy, żalu czy wstydu. Debaty w prasie również wskazywały na konieczność redefinicji rozumienia polskości i odczuwania kolektywnych emocji związanych z ujawnionymi przez historyków wydarzeniami. 
Prowadziło to do sytuacji, w której większość Polaków nie tylko owych emocji nie odczuwała (na co wskazuje wiele badań, choćby Polski Sondaż Uprzedzeń), ale także odrzucała samą wiedzę historyczną - kwestionując źródła tej wiedzy, cenzurując autorów, wyjaśniając nowo poznane fakty tak, by pozwoliło to na podtrzymanie wysokiej samooceny narodowej. Dyskusję o historii narodu należałoby więc prowadzić z pominięciem emocji i aluzji do zbiorowej odpowiedzialności czytelników ${ }^{46}$.

Oprócz tego rodzaju zabiegów samych autorów prac historycznych niezbędne jest też wypracowanie innych form tożsamości społecznej, które będą dostępne na równi z tożsamością narodową. Praktycznie wszystkie z omówionych powyżej strategii regulacji negatywnych emocji moralnych są szczególnie często wykorzystywane przez ludzi o bardzo silnej identyfikacji narodowej - osoby te zrobią wszystko, by odsunąć od siebie ryzyko odczucia winy, żalu bądź wstydu związanych z postępowaniem własnego narodu. Wiele badań psychologicznych wskazuje, że dostępność szerszych tożsamości (my-Europejczycy; my-ludzie) może mieć zbawienny wpływ na zdolność do pogodzenia się z negatywnymi epizodami historii własnego narodu. Badania Kofty i Sławuty wskazały, że wystarczy aktywizować wspólnotę współczesnych tożsamości Polaków i Żydów, by Polacy byli bardziej gotowi przyjąć historię powojennych pogromów i przestali dehumanizować ich ofiary ${ }^{\mathbf{4 7}}$. Posiadanie takiej nadrzędnej tożsamości (np. my-Europejczycy) ogranicza rywalizację cierpień i ułatwia dostrzeżenie cierpienia ofiar niebędących naszymi rodakami ${ }^{48}$. Dowiedliśmy w ostatnich badaniach, że Polacy posiadający nadrzędne tożsamości są bardziej gotowi do pojednania z narodami, które w przeszłości dokonały zbrodni na Polakach ${ }^{49}$.

46 Nawet w skądinąd znakomitej książce Sq̨siedzi... [Por. J.T. Gross Sąsiedzi. Historia zagłady żydowskiego miasteczka, Fundacja Pogranicze, Sejny 2000] znalazł się cały rozdział, w którym autor implikuje zbiorową odpowiedzialność narodową czytelników - zastrzegając jednak, że nie chodzi mu o zbiorowe poczucie winy.

47 M. Kofta, P. Slawuta Thou shall not kill... your brother: Victim - perpetrator cultural closeness and moral disapproval of Polish atrocities against Jews after the Holocaust.

48 J.R. Vollhardt "Crime against humanity" or "crime against Jews"? Acknowledgment in construals of the Holocaust and its importance for intergroup relations, "Journal of Social Issues" 2013 No. 69/1, s. 144-161. L. Andrighetto, S. Mari, C. Volpato, B. Behluli Reducing competitive victimhood in Kosovo: The role of extended contact and common ingroup identity, "Political Psychology" 2012 No. 33/4, s. 513-529.

K. Hamer, M. Penczek, M. Bilewicz "Humanum ignoscere est”. The relationship of national and supranational identifications with intergroup forgiveness, "Personality and Individual Differences" 2017 No. 105 , s. $257-263$. 
Wyjściem z zaklętego kręgu sprawnej regulacji emocji jest więc wypracowanie nowego modelu tożsamości, w którym tożsamość narodowa współwystępuje z tożsamościami lokalnymi, regionalnymi i globalnymi - co ogranicza defensywne reakcje na historię. Po drugie zaś niezbędne jest takie prowadzenie debat historycznych, które koncentruje się na faktach i interpretacjach, przy jednoczesnym niewzbudzaniu kolektywnych emocji moralnych u niegotowych na takie zabiegi czytelników.

\section{Abstract}

\section{Michał Bilewicz}

UNIVERSITY OF WARSAW

The Poles' Collective (Im)Memory as Effective Emotion Regulation

Bilewicz applies notions borrowed from the psychology of emotions to understand collective (im)memory in Poland, with a particular focus on defensive reactions to new historical data on Poles' negative behaviour. Based on James Gross' concept of emotion regulation, Bilewicz elaborates a model of downregulating collective moral emotions (such as guilt and shame). He then applies this model to the debate on the Jedwabne pogrom. He also outlines systematic social psychological studies that support his proposed emotion downregulation model. The article concludes with a discussion of alternative ways of presenting negative history - ways that overcome those defensive emotion regulatory processes.

\section{Keywords}

(im)memory, control of emotions, Jedwabne, attribution 